\title{
The Influence of Brand Image Towards Brand Loyalty of Dental Hospital of Universitas Muhammadiyah Yogyakarta
}

\section{Regia Aristiyanto*}

* Correspondence author: regia230388@gmail.com

* Master of Hospital Management, Universitas Muhammadiyah Yogyakarta, Yogyakarta, Indonesia

\section{N D E X I N G}

Keywords:

Brand image;

Strength of brand

association;

Favorability of brand

association;

Uniqueness of brand

association;

Brand loyalty

\begin{abstract}
A B S T R AC T
The change of hospital image become socio-economic organizations requires hospital has to be able to finance its operations and compete to gain the market share. Dental Hospital of Univesitas Muhammadiyah Yogyakarta is hospital in Yogyakarta. Hospital uses various marketing strategies to seize and retain consumer. One of them is making good brand image to get consumer loyalty. The purpose of study was to determine the influence of brand image towards brand loyalty of Dental Hospital of Universitas Muhammadiyah Yogyakarta. The type study was quantitative research with causality and descriptive explanation. The samples were dental specialist pastient of Dental Hospital of Universitas Muhammadiyah Yogyakarta who had visited more than once with quota sampling technique. Data analysis was multiple regression analysis. The results showed brand image dimensions had a positive and significant simultaneously influence toward consumer loyalty of Dental Hospital of Universitas Muhammadiyah Yogyakarta. The favorability of brand association and uniqueness of brand association had positive and significant influence towards brand loyalty, while the strength of brand association had positive and insignificant influence towards brand loyalty. The conclusion of the study showed brand image had a positive and significant influence towards brand loyalty of Dental Hospital of Universitas Muhammadiyah Yogyakarta.
\end{abstract}

\begin{abstract}
Perubahan citra rumah sakit menjadi organisasi sosio-ekonomis mengharuskan rumah sakit mampu membiayai operasional dan bersaing untuk mendapatkan pangsa pasar. Rumah Sakit Gigi dan Mulut Universitas Muhammadiyah Yogyakarta (RSGM UMY) merupakan rumah sakit khusus gigi dan mulut di Yogyakarta. Rumah sakit menggunakan berbagai strategi pemasaran untuk merebut dan mempertahankan konsumen, salah satunya dengan membentuk citra merek yang baik untuk mendapatkan loyalitas konsumen. Tujuan penelitian ini adalah untuk mengetahui pengaruh citra merek terhadap loyalitas merek RSGM UMY. Jenis penelitian adalah penelitian kuantitatif dengan penjelasan kausalitas dan deskriptif. Sampel yang digunakan adalah pasien poli gigi umum dan spesialis RSGM UMY yang telah melakukan kunjungan lebih dari satu kali teknik pengambilan sampel quota sampling. Analisis data yang digunakan adalah analisis regresi berganda. Hasil penelitian menunjukkan bahwa dimensi citra merek berpengaruh positif dan signifikan secara simultan terhadap loyalitas merek. Keunggulan asosiasi merek dan keunikan asosiasi merek berpengaruh positif dan signifikan terhadap loyalitas merek, sedangkan kekuatan asosiasi merek berpengaruh positif dan tidak signifikan terhadap loyalitas merek RSGM UMY. Kesimpulan penelitian adalah citra merek berpengaruh positif dan signifikan terhadap loyalitas merek RSGM $U M Y$.
\end{abstract}

(C) 2018 JMMR. All rights reserved

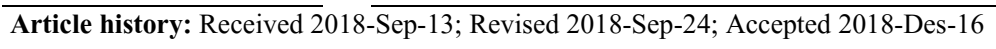

\section{INTRODUCTION}

The hospital is a health service institution that carries on individual health services that provides inpatient, outpatient and emergency services $\stackrel{1}{-}$. The hospital must be able to finance its operations in order to the hospital function can be carried out properly. It causes the image change of the hospital, which is a social function to an economic function, so that the image of hospital has change into a socio-economic organization.
Potential of market potential in Indonesia makes hospital owners and managers must compete to reach markets that can provide financial benefits to hospitals. One of the challenges was how to gain and maintain market share, so that the owner and manager of the hospital has to develop and design a marketing strategy that can support its business.

Brand image is the consumer's assessment of the brand in a market. Creation can be created based on personal 
experience or hearing his reputation from other people or the media 2 .

According to Schiffman and Kanuk, Brand loyalty is consumer preference consistently to make purchases on the same brand on specific products or certain service categories ${ }^{3}$.

Table 1. The Number of Dental Specialist Patient of Dental Hospital of Universitas Muhammadiyah Yogyakarta in 2013, 2014, 2015 dan 2016

\begin{tabular}{lcccc}
\multicolumn{1}{c}{ Month } & \multicolumn{3}{c}{ Year } & $\mathbf{2 0 1 6}$ \\
\hline January & $\mathbf{2 0 1 3}$ & $\mathbf{2 0 1 4}$ & $\mathbf{2 0 1 5}$ & 619 \\
February & 718 & 727 & 664 & 593 \\
March & 619 & 766 & 722 & 636 \\
April & 617 & 814 & 816 & 692 \\
May & 632 & 858 & 821 & 601 \\
June & 596 & 770 & 717 & 574 \\
July & 582 & 816 & 754 & 468 \\
August & 642 & 524 & 536 & 770 \\
September & 512 & 688 & 660 & 613 \\
October & 650 & 769 & 729 & 716 \\
November & 753 & 701 & 831 & 658 \\
Desember & 774 & 611 & 701 & 780 \\
\multicolumn{1}{r}{ Total } & 800 & 650 & 657 & 7720 \\
\hline
\end{tabular}

Resource: Management Information System of Dental Hospital of

Univesitas Muhammadiyah Yogyakarta, 2017

Brand image is the opinion, attitude and emotion of consumer toward a brand that reflects the cognitive or psychological elements of a brand. Brand loyalty is relationship measurement between customer and brand. The measurement can provide a possibility overview of consumer that switch to another product, especially if a brand has changed, whether price or other attributes ${ }^{4}$.

The Health Profile of the Special Region of Yogyakarta (DIY) in 2013 shows that dental pulp disease is one of the diseases that includes to top 10 diseases in DIY. This condition shows that the demand of dental and oral health services in DIY was still high. Dental Hospital of Universitas Muhammadiyah Yogyakarta is a special hospital located in DIY. Dental Hospital of Universitas Muhammadiyah Yogyakarta has complete dental and oral health service because it has all dental specialist services of dentistry and completes dental supporting facilities. The condition should make Dental Hospital of Universitas Muhammadiyah Yogyakarta became as market leader in dental and oral health services, especially in DIY.

Table 1 show the patient number of dental specialist of Dental Hospital of Universitas Muhammadiyah Yogyakarta was increased in 2014, but there was decreased of patient number in 2015 and $2016 \stackrel{5}{ }$.

Based on the description, the study problem that can be formulated is "Does the brand image towards the brand loyalty of the Dental Hospital of Universitas Muhammadiyah Yogyakarta?"

The purpose of this study were to determine the influence of brand image towards the brand loyalty of Dental Hospital of Universitas Muhammadiyah Yogyakarta and to determine the influence brand image dimension towards the brand loyalty of Dental Hospital of Universitas Muhammadiyah Yogyakarta.

This study was expected to be useful on the theoretical aspect, those are a data resource for similar study reference, literature resource and provide idea about marketing management, as well as useful on practical aspect, those are obtained an overview of brand image and brand loyalty of Dental Hospital of Universitas Muhammadiyah Yogyakarta and it can be used as one the base for Dental Hospital of Universitas Muhammadiyah Yogyakarta manager to determine the right strategy to develop the product, obtained an overview of the influence of brand image towards the brand loyalty of Dental Hospital of Universitas Muhammadiyah Yogyakarta and provide advice to the development of marketing strategies for Dental Hospital of Universitas Muhammadiyah Yogyakarta.

\section{RESEARCH METHOD}

Type of study is quantitative study that explain causality and descriptive. The populations were dental 
specialist patient of Dental Hospital of Universitas Muhammadiyah Yogyakarta who had visited more than once. The number of study sample was 100 patients with quota sampling technique. Data collection was done by assumption test consist of normality test, multicollinearity test and heteroscedasticity test. Data analysis was used multiple regression analysis. The hypotheses were:

$\mathrm{H}_{1}$ : Brand image with strength of brand association, favorability of brand association and uniqueness of brand association has influence simultaneously towards brand loyalty of Dental Hospital of Universitas Muhammadiyah Yogyakarta.

$\mathrm{H}_{2}$ : Strength of brand association has influence partially towards brand loyalty of Dental Hospital of Universitas Muhammadiyah Yogyakarta.

$\mathrm{H}_{3}$ : Favorability of brand association has influence partially towards brand loyalty of Dental Hospital of Universitas Muhammadiyah Yogyakarta. questionnaire with Likert scale. Validity test and reliability test was used Pearson Correlation test and Cronbach Alpha test. The data presentation was carried out by descriptive analysis. Regression equation was tested with classic.

$\mathrm{H}_{4}$ : Uniqueness of brand association has influence partially towards brand loyalty of Dental Hospital of Universitas Muhammadiyah Yogyakarta.

\section{RESULT AND DISCUSSION}

\section{Validitas Test and Reability Test}

Validity test shows all statement of questionnaire about brand image dimensions and brand loyalty had value of $r$ was positive and the value of $r$ was more than 0.3 (table 2), so that all the statements were valid. Reliability test of all statement of the questionnaire about brand image dimensions and brand loyalty showed value of Cronbach Alpha was 0.973 (table 3), so that all statements were reliable.

Table 2. Validity Test Result

\begin{tabular}{|c|c|c|c|}
\hline Variable & Statement & Value of $\mathbf{r}$ & Status \\
\hline \multirow{11}{*}{$\begin{array}{l}\text { Strength of } \\
\text { Brand } \\
\text { Association }\end{array}$} & 1 & 0,797 & Valid \\
\hline & 2 & 0,760 & Valid \\
\hline & 3 & 0,799 & Valid \\
\hline & 4 & 0,742 & Valid \\
\hline & 5 & 0,481 & Valid \\
\hline & 6 & 0,593 & Valid \\
\hline & 7 & 0,751 & Valid \\
\hline & 8 & 0,851 & Valid \\
\hline & 9 & 0,883 & Valid \\
\hline & 10 & 0,867 & Valid \\
\hline & 11 & 0,836 & Valid \\
\hline \multirow{3}{*}{$\begin{array}{l}\text { Favorability of } \\
\text { Brand }\end{array}$} & 1 & 0,896 & Valid \\
\hline & 2 & 0,900 & Valid \\
\hline & 3 & 0,792 & Valid \\
\hline \multirow[t]{3}{*}{ Association } & 4 & 0,881 & Valid \\
\hline & 5 & 0,878 & Valid \\
\hline & 6 & 0,780 & Valid \\
\hline Uniqueness of & 1 & 0,848 & Valid \\
\hline Brand & 2 & 0,730 & Valid \\
\hline \multirow[t]{2}{*}{ Association } & 3 & 0,892 & Valid \\
\hline & 4 & 0,756 & Valid \\
\hline \multirow{4}{*}{ Brand loyalty } & 1 & 0,781 & Valid \\
\hline & 2 & 0,698 & Valid \\
\hline & 3 & 0,810 & Valid \\
\hline & 4 & 0,589 & Valid \\
\hline
\end{tabular}

Resource: SPSS output, 2018 
Table 3. Reability Test Result

\begin{tabular}{lc}
\hline Cronbach's Alpha & N of Items \\
\hline .973 & 25 \\
\hline \multicolumn{2}{c}{ Resource: SPSS output, 2018}
\end{tabular}

\section{Descriptive Analysis}

The characteristic description of respondent based on gender was present in table 4 .

Table 4. Respondent Characteristic Based on

Gender

\begin{tabular}{ccc}
\hline Gender & Frequency & Persentage \\
\hline Male & 39 & $39 \%$ \\
Female & 61 & $61 \%$ \\
Total & 100 & $100 \%$ \\
\hline
\end{tabular}

Resource: primer data, 2018

Table 4 shows male respondent was 39 persons (39\%) and female respondent was 61 persons (61\%). It can concluded that mayority respondent based on gender was female (61 persons).

The characteristic description of respondent based on age was present in table 5 .

Table 5. Respondent Characteristic Based on Age

\begin{tabular}{ccc}
\hline Age (Years Old) & Frequency & Persentage \\
\hline $17-27$ & 46 & $46 \%$ \\
$28-38$ & 29 & $29 \%$ \\
$39-49$ & 14 & $14 \%$ \\
$>49$ & 11 & $11 \%$ \\
Total & 100 & $100 \%$ \\
\hline
\end{tabular}

Resource: primer data, 2018

Table 5 shows respondent at 17-27 years old was 46 persons (46\%), at 28-38 years old was 29 persons (29\%), at 39-49 years old was 14 person (14\%) and more than 49 years old was 11 persons $(11 \%)$. It can concluded that mayority respondent based on age was 17-27 years old (46 persons).

The characteristic description of respondent based on occupation was present in table 6 .
Table 6. Respondent Characteristic Based on Occupation

\begin{tabular}{lcc}
\hline \multicolumn{1}{c}{ Occupation } & Frequency & Persentage \\
\hline Student & 42 & $42 \%$ \\
Housewife & 8 & $8 \%$ \\
Government & 10 & $10 \%$ \\
employees & 21 & $21 \%$ \\
Private employees & 13 & $13 \%$ \\
Entrepreneur & 6 & $6 \%$ \\
Other (retired) & 100 & $100 \%$ \\
Total & &
\end{tabular}

Table 6 shows student respondent was 42 persons (42\%), housewife was 8 persons $(8 \%)$, government employees was 10 persons $(10 \%)$, private employees was 21 persons (21\%), entrepreneur was 13 persons (13\%) and other (retired) was 6 persons $(6 \%)$. It can concluded that mayority respondent based on occupation was student (42 persons).

The characteristic description of respondent based on expenditure was present in table 7 .

Table 7. Respondent Characteristic Based on Expenditure

\begin{tabular}{lcc}
\hline $\begin{array}{c}\text { Expenditure } \\
\text { Average per } \\
\text { Month }\end{array}$ & Frequency & Persentage \\
\hline$<$ Rp2.500.000 & 43 & $43 \%$ \\
Rp2.500.000- & 25 & $25 \%$ \\
Rp5.000.000 & & $18 \%$ \\
Rp5.000.001 - & 18 & $8 \%$ \\
Rp7.500.000 & & $6 \%$ \\
Rp7.500.001 - & 8 & $100 \%$ \\
Rp10.000.000 & 6 & \\
$>$ Rp10.000.000 & 100 & \\
Total &
\end{tabular}

Resource: primer data, 2018

Table 7 shows respondent with expenditure average per month less than Rp2.500.000 was 43 persons (43\%), expenditure average per month Rp2.500.000 - Rp5.000.000 was 25 persons $(25 \%)$, expenditure average per month Rp5.000.001 - Rp7.500.000 was 18 persons (18\%), expenditure average per month Rp7.500.001 Rp10.000.000 was 8 persons ( $8 \%$ ), and expenditure average per month more than Rp10.000.000 was 6 persons $(6 \%)$. It can concluded that mayority respondent based on 
expenditure average per month was less than Rp2.500.000 (43 persons).

\section{Classic Assumption Test}

Normality test with Kolmogorov-Smirnov analysis showed on table 8 .

\section{Tabel 8. Normality Test Result}

\begin{tabular}{lcc}
\hline \multicolumn{1}{c}{ Variable } & Significant & Explanation \\
\hline $\begin{array}{l}\text { Strength of Brand } \\
\text { Association }\end{array}$ & 0,689 & Normal \\
$\begin{array}{l}\text { Favorability of } \\
\text { Brand Association }\end{array}$ & 0,990 & Normal \\
$\begin{array}{l}\text { Uniqueness of } \\
\text { Brand Association } \\
\text { Brand Image }\end{array}$ & 0,893 & Normal \\
\hline
\end{tabular}

Resource: SPSS output, 2018

Normality test result showed all of variable has significance value was more than 0,05 (sig $>0,05)$. It concluded that the data has normal distribution. Multicollinearity test result showed on table 9.

Table 9. Multicollinearity Test Result

\begin{tabular}{|c|c|c|c|}
\hline Dimension & Tol. & VIF & Con. \\
\hline $\begin{array}{l}\text { Strength of Brand } \\
\text { Association }\end{array}$ & 0,330 & 3,029 & \\
\hline $\begin{array}{l}\text { Favorability of } \\
\text { Brand } \\
\text { Association }\end{array}$ & 0,360 & 2,776 & $\begin{array}{l}\text { Ihere } \\
\text { was no } \\
\text { multicoll }\end{array}$ \\
\hline $\begin{array}{l}\text { Uniqueness of } \\
\text { Brand } \\
\text { Association }\end{array}$ & 0,492 & 2,032 & nearity \\
\hline
\end{tabular}

Multicollinearity test result showed all of variable has tolerance value more than 0,1 and VIF value less than 10 . It can concluded that regression model has no multicollinearity. Heteroscedasticity test result showed on table 10

Table 10. Heteroscedasticity test result

\begin{tabular}{lcc}
\hline \multicolumn{1}{c}{ Dimension } & Significant & Explanation \\
\hline $\begin{array}{l}\text { Strength of } \\
\text { Brand }\end{array}$ & 0,297 & $\begin{array}{c}\text { There was no } \\
\text { Heterosce-dasticity }\end{array}$ \\
$\begin{array}{l}\text { Association } \\
\text { Favorability of } \\
\text { Brand }\end{array}$ & 0,133 & $\begin{array}{c}\text { There was no } \\
\text { Heterosce-dasticity }\end{array}$ \\
$\begin{array}{l}\text { Association } \\
\text { Uniqueness of } \\
\text { Brand }\end{array}$ & 0,715 & $\begin{array}{c}\text { There was no } \\
\text { Heterosce-dasticity }\end{array}$ \\
\hline
\end{tabular}

Resource: SPSS output, 2018
Heteroscedasticity test result showed all of variable has significance value was more than 0,05 ( $\mathrm{sig}>0,05$ ). It can concluded that the data has normal distribution. It can concluded that regression model has no heteroscedasticity.

\section{Multiple Regression Analysis}

Multiple regression analysis result showed on table 11. Multiple regression analysis showed $\beta$ value (constant) was 3,696 , regression coefficient $X_{1}$ was 0,025 , regression coefficient $X_{2}$ was 0,151 and regression coefficient $X_{3}$ was 0,442 , so that the multiple regression equation can be written as:

$\mathrm{Y}=3,696+0,025 \mathrm{X}_{1}+0,151 \mathrm{X}_{2}+0,442 \mathrm{X}_{3}$

The regression equation models in standardized regression equation were:

1. Constant coefficient was 3,696 it means independent variable (strength of brand association, favorability of brand association dan uniqueness of brand association) has positive influence towards brand loyalty of Dental Hospital of Universitas Muhammadiyah Yogyakarta

2. Regression coefficient $(\beta) X_{1}$ was 0,025 . It means strength of brand association has positive influence towards brand loyalty of Dental Hospital of Universitas Muhammadiyah Yogyakarta.

3. Regression coefficient $(\beta) X_{2}$ was 0,151 . It means favorablity of brand association has positive influence towards brand loyalty of Dental Hospital of Universitas Muhammadiyah Yogyakarta.

4. Regression coefficient $(\beta) X_{3}$ was 0,442 . It means uniqueness of brand association has positive influence towards brand loyalty of Dental Hospital of Universitas Muhammadiyah Yogyakarta.

Based on the equation, it can concluded uniqueness of brand association was most influence toward brand loyalty and strength of brand association was lowest influence toward brand loyalty.

\section{Hypothesis Test}

The determination coefficient test result showed that the coefficient of determination (Adjusted R Square) was 0.526 (Table 12). This value means $52.6 \%$ of brand loyalty can be explained by strength of brand association, favorability of brand association and uniqueness of brand association the variables. While $47.4 \%$ of brand loyalty was influenced by other variables not examined in this study. 
Simultaneous test result (test F) was shown in Table 13. The influence of independent variables simultaneously toward the dependent variable showed that the calculated $\mathrm{F}$ value was more than $\mathrm{F}$ table value $(27.697>2.70)$ with significant value less than $0.05(0.000)$. It can concluded strength of brand associations, the favorability of brand associations and the uniqueness of brand associations have a significant influence simultaneously toward consumer loyalty.

Table 11. Multiple Regression Analysis Result Coefficients ${ }^{\mathrm{a}}$

\begin{tabular}{lcccr}
\hline & \multicolumn{2}{c}{ Unstandardized Coefficients } & \multicolumn{2}{c}{ Standardized Coefficients } \\
Model & B & Std. Error & Beta & t Sig. \\
\hline 1 (Constant) & 3.696 & 1.366 & & 2.706 .009 \\
Strength of Brand Association & .025 & .062 & .057 & .401 .689 \\
Favorability of Brand Association & .151 & .087 & .234 & 1.729 .088 \\
Uniqueness of Brand Association & .442 & .099 & .518 & 4.485 .000 \\
a. Dependent Variable: Brand_image & & & & \\
\hline Resource: primer data, 2018 & & & &
\end{tabular}

Table 12. Determination coefficient test result

\begin{tabular}{ccccc}
\hline \multicolumn{5}{c}{ Model Summary $^{\mathbf{b}}$} \\
\hline Model & $\mathrm{R}$ & R Square & Square & Std. Error \\
1 & $.739^{\mathrm{a}}$ & .546 & .526 & 1.540 \\
& \multicolumn{3}{c}{ a. Predictors: (Constant) } \\
\multicolumn{4}{c}{ b. Dependent Variable: brand loyalty } \\
\hline
\end{tabular}

Resource: SPSS output, 2018

The hypothesis that state the strength of brand associations, favorability of brand associations and uniqueness of brand associations simultaneously have positive influence towards consumer loyalty can be accepted $\left(\mathrm{H}_{0}\right.$ was rejected and $\mathrm{H}_{1}$ was accepted $)$.

The partial test result (test $\mathrm{t}$ ) was shown in table 14 . The partial test result between strength of brand association variable towards brand loyalty showed the regression coefficient value of the strength of brand association was 0.025 and has positive value. It can concluded that the strength of brand association has positive influence towards brand loyalty. Positive influence means the brand loyalty will increase if strength of brand association was increases. Regression analysis has a significance value was 0.689 (> 0.10 at $90 \%$ confidence level). It was concluded that $\mathrm{H}_{0}$ was accepted and $\mathrm{H}_{2}$ was rejected, meaning that the strength of brand association had no significant influence towards on brand loyalty.
The partial test result between favorablity of brand association variable towards brand loyalty showed the regression coefficient value of the favorablity of brand association was 0.151 and has positive value. It can concluded that the favorablity of brand association has positive influence towards brand loyalty. Positive influence means the brand loyalty will increase if favorablity of brand association was increase. Regression analysis has a significance value was $0.088(<0.10$ at $90 \%$ confidence level). It was concluded that $\mathrm{H}_{0}$ was rejected and $\mathrm{H}_{3}$ was accepted, meaning that the favorablity of brand association had significant influence towards on brand loyalty.

The partial test result between uniqueness of brand association variable towards brand loyalty showed the regression coefficient value of the favorablity of brand association was 0.442 and has positive value. It can concluded that the uniqueness of brand association has positive influence towards brand loyalty. Positive influence means the brand loyalty will increase if uniqueness of brand 
association was increase. Regression analysis has a significance value was $0.000(<0.10$ at $90 \%$ confidence level). It was concluded that $\mathrm{H}_{0}$ was rejected and $\mathrm{H}_{4}$ was accepted, meaning that the uniqueness of brand association had significant influence towards on brand loyalty.

Tabel 13. Simultaneous Test Result (Test F)

\begin{tabular}{|c|c|c|c|c|c|c|}
\hline \multicolumn{7}{|c|}{ ANOVA $^{b}$} \\
\hline \multicolumn{2}{|c|}{ Model } & Sum of Squares & df & Mean Square & $\mathbf{F}$ & Sig. \\
\hline 1 & Regression & 196.992 & 3 & 65.664 & 27.679 & $.000^{\mathrm{a}}$ \\
\hline & Residual & 163.693 & 69 & 2.372 & & \\
\hline & Total & 360.685 & 72 & & & \\
\hline
\end{tabular}

a. Predictors: (Constant), Strength of Brand Assoc., Favorability of Brand Assoc., Uniqueness of Brand Assoc.

b. Dependent Variable: brand loyalty

Resource: SPSS output, 2018

Tabel 14. Partial Test Result (Test $t$ )

\begin{tabular}{llrrrrr}
\hline & \multicolumn{2}{c}{ Unstandardized Coefficients } & \multicolumn{2}{c}{$\begin{array}{c}\text { Standardized } \\
\text { Coefficients }\end{array}$} & & \\
\cline { 2 - 4 } Model & \multicolumn{1}{c}{ B } & Std. Error & Beta & \multicolumn{1}{c}{ t } & \multicolumn{1}{c}{ Sig. } \\
\hline $1 \quad$ (Constant) & 3.696 & 1.366 & & & 2.706 & .009 \\
& Strength of Brand Association & .025 & .062 & .057 & .401 & .689 \\
Favorability of Brand Association & .151 & .087 & .234 & 1.729 & .088 \\
Uniqueness of Brand Association & .442 & .099 & .518 & 4.485 & .000 \\
\hline
\end{tabular}

Resource: primer data, 2018

\section{Discussion}

The data analysis showed that all brand image variables (strength of brand association, favorability of brand association and uniqueness of brand association) have a positive and significant influence simultaneously with calculated $\mathrm{F}$ value more than $\mathrm{F}$ table and a significance value was $0.000(<0,05)$. It means that all of brand image dimensions of Dental Hospital of Universitas Muhammadiyah Yogyakarta were the consumers' decisions basic to be loyal to Dental Hospital of Universitas Muhammadiyah Yogyakarta.

Brand image that has been established by Dental Hospital of Universitas Muhammadiyah Yogyakarta was the consumer loyalty consederation to Dental Hospital of Universitas Muhammadiyah Yogyakarta. Complete dental specialist and dental supporting facilities were Dental Hospital of Universitas Muhammadiyah Yogyakarta's superiority compared to competitors. It is appropriate with the theory that state the image was a perception that relatively consistent in the long term (enduring perception) and formed by a product has advantages and different compared to competing products ${ }^{10}$. It can be said that the consumer loyalty of Dental Hospital of Universitas
Muhammadiyah Yogyakarta was established by image that has been built by Dental Hospital of Universitas Muhammadiyah Yogyakarta. It is accord to statement that consumers who perceive the image of product will either make a repurchase and become loyal to the product ${ }^{-}$.

The result of a partial test between strength of brand association and consumer loyalty showed a regression coefficient was 0.025 and has positive value. Its mean strength of brand association which consists of attributes and benefits has influence consumer loyalty toward Dental Hospital of Universitas Muhammadiyah Yogyakarta product. However, the influence of strength of brand association towards consumer loyalty of Dental Hospital of Universitas Muhammadiyah Yogyakarta has not significant influence. Strength of brand association can help consumers to build their image and know the brand, so that it becomes a reason for consumers to use or buy the product. A good strength of brand association has a positive effect on consumer attitudes so that consumers will make repeat purchases and become loyal consumer of a brand. The strength of the brand association of Dental Hospital of Universitas Muhammadiyah Yogyakarta shows a positive influence towards consumer loyalty of Dental Hospital of Universitas Muhammadiyah Yogyakarta. 
Positive influence can happen because consumers perceive Dental Hospital of Universitas Muhammadiyah Yogyakarta as a company with good facilities, friendly and responsive officers, affordable costs and able to solve dental and oral problems of consumers. These things can become strength of brand association of Dental Hospital of Universitas Muhammadiyah Yogyakarta, thus built product information and establish a good image in the consumers mind.

The result of a partial test between favorability of brand association and brand loyalty show a regression coefficient of 0.151 and has positive value. This showed that the favorability of brand association has influence towards consumers' loyalty of Dental Hospital of Universitas Muhammadiyah Yogyakarta product.Brand favorability makes consumers believe that the attribute and benefit of brand can satisfy the consumers, so that a positive attitude on the brand was created. Good service quality, safety and comfort, and pride to Dental Hospital of Universitas Muhammadiyah Yogyakarta were dimensions that can satisfy consumers of Dental Hospital of Universitas Muhammadiyah Yogyakarta. Consumer satisfaction was able to meet the consumer necessary, so that the purpose of purchase a product can be achieved. It is accord to statement that consumer satisfaction was goal of purchase a brand and customer satisfaction can be achieved if the product provided reaches or exceeds consumer expectation $\stackrel{8}{ }$.

The result of a partial test between uniqueness of brand association variable and brand loyalty show a regression coefficient of 0.442 and has positive value. This shows that the uniqueness of brand association has influence towards consumers' loyalty of Dental Hospital of Universitas Muhammadiyah Yogyakarta product. Complete dental specialist and dental supporting facilities were Dental Hospital of Universitas Muhammadiyah Yogyakarta's uniqueness. It may allow consumer can be treated comprehensively in one dental health facility. These uniquenesses were a Dental Hospital of Universitas Muhammadiyah Yogyakarta hallmark, so that it was difficult to replicate by other brand. The uniqueness gives a certain impression that consumer remember the products easily, so that consumer want to know more about the product. Consumer's desire to find out more about the product can make a positive impression that can imprint in the consumer's memory so that consumers will feel comfort with the brand. It will be makes consumer remember certain brands even though there are similar product, so that consumer loyalty can increase $\frac{11}{}$.
The study result was accordance with the research conducted by Al-Abdallaha and Aborumman (2013) which states that there was a significant influence between brand associations on brand loyalty, and Iqbal and Adami's (2013) research which states that brand image has a positive influence on brand loyalty of Close up toothpaste $\frac{12}{2}$.

\section{CONCLUSION}

Based on the study result and discussion, the following conclusions can be drawn: Brand image through strength of brand associations, favorability of brand associations and the uniqueness of brand associations had a positive influence simultaneously and was significant toward brand loyalty of Dental Hospital of Universitas Muhammadiyah Yogyakarta. Strength of brand association had no significant influence partially towards brand loyalty of Dental Hospital of Universitas Muhammadiyah Yogyakarta. Favorability of brand association had significant influence partially towards brand loyalty of Dental Hospital of Universitas Muhammadiyah Yogyakarta. Uniqueness of brand association had no significant influence partially towards brand loyalty of Dental Hospital of Universitas Muhammadiyah Yogyakarta.

\section{REFERENCE}

1. Peraturan Menteri Kesehatan Nomor 56 Tahun 2014, Klasifikasi dan Perizinan Rumah Sakit, 18 Agustus 2014, Berita Negara Republik Indonesia Tahun 2014 Nomor 1221, Jakarta

2. Hestanto. 2017. Citra Merek (brand image) Menurut Para Ahli, access 28 November 2017. https://www.hestanto.web.id/citra-merek-brand-imagemenurut-para-ahli/

3. Schiffman, L.G dan L.L. Kanuk. 2009. Customer Behavior, New Jersey : Prentice- Hall International, Inc.

4. Andrologi F, 2014, Analisis Pengaruh Brand Image dan Brand Awareness Terhadap Brand Loyalty dan Dampaknya Terhadap Brand Equity, Semarang

5. Cronin, J. Joseph dan Steven A. Taylor. 1992. "Measuring services quality : a reexamination and extension.” Journal of Marketing, Vol. 56 July 1992): 55-68.

6. Rangkuti F, 2009. The Power of Brand, PT. Gramedia Pustaka Utama, Jakarta

7. Kotler P, Amstrong G, 2012, Principles of Marketing, 14th edn, Prentice-Hall, Inc., Boston 
8. Keller KL, 2013, Building, Measuring, and Managing Brand Equity, Global Edition, Pearson Education, Inc., England

9. Solomon M, Bamossy G, Askegaard S, Hogg MK, 2006, Consumer Behaviour, 3rd edn, Prentice-Hall Inc., USA

10. Kotler P, 2002, Marketing, management, millenium edition, 10th edn, Prentice-Hall, Inc., Boston

11. Aaker DA, 1991, Managing Brand Equity, Capitalizing on the Value of a Brand Name. Free Press: New York

12. Dr. Ghaith Mustafa Al-Abdallah, Dr. Assd H. AboRumman, The Effect of Brand Associations on Customer (2013) Loyalty: Empirical Study on Mobile Devices in Jordan* American Academic \& Scholarly Research Journal Vol. 5, No. 1, Jan. 2013, http://www.naturalspublishing.com/files/published/369 d37x94k9bi5.pdf 